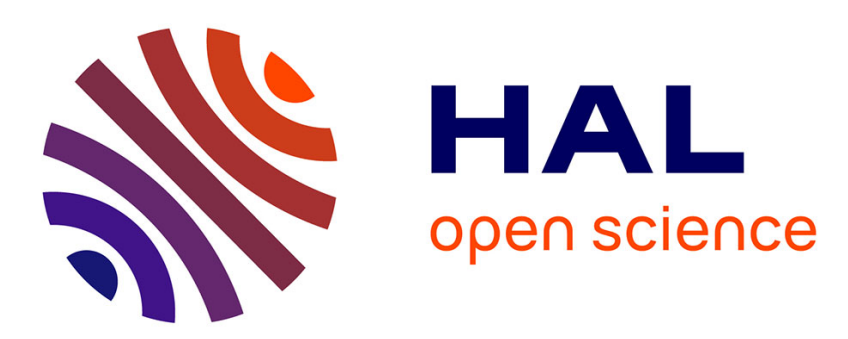

\title{
Rethinking Human-Nonhuman Primate Contact and Pathogenic Disease Spillover
}

\author{
Victor Narat, Lys Alcayna-Stevens, Stephanie Rupp, Tamara Giles-Vernick
}

\section{To cite this version:}

Victor Narat, Lys Alcayna-Stevens, Stephanie Rupp, Tamara Giles-Vernick. Rethinking HumanNonhuman Primate Contact and Pathogenic Disease Spillover. EcoHealth, 2017, 10.1007/s10393017-1283-4 . hal-02159223

\section{HAL Id: hal-02159223 \\ https://hal.science/hal-02159223}

Submitted on 16 Sep 2019

HAL is a multi-disciplinary open access archive for the deposit and dissemination of scientific research documents, whether they are published or not. The documents may come from teaching and research institutions in France or abroad, or from public or private research centers.
L'archive ouverte pluridisciplinaire HAL, est destinée au dépôt et à la diffusion de documents scientifiques de niveau recherche, publiés ou non, émanant des établissements d'enseignement et de recherche français ou étrangers, des laboratoires publics ou privés. 


\title{
Rethinking Human-Nonhuman Primate Contact and Pathogenic Disease Spillover
}

\author{
Victor Narat, ${ }^{1}$ Lys Alcayna-Stevens, ${ }^{1}$ Stephanie Rupp, ${ }^{2}$ and Tamara Giles-Vernick ${ }^{1,3}$ \\ ${ }^{1}$ Emerging Diseases Epidemiology Unit, Institut Pasteur, 25-28 rue du Docteur Roux, 75724 Paris Cedex, France \\ ${ }^{2}$ Department of Anthropology, City University of New York - Lehman College, Bronx, NY \\ ${ }^{3}$ Canadian Institute for Advanced Studies, Toronto, Canada
}

\begin{abstract}
Zoonotic transmissions are a major global health risk, and human-animal contact is frequently raised as an important driver of transmission. A literature examining zooanthroponosis largely agrees that more human-animal contact leads to more risk. Yet the basis of this proposition, the term contact, has not been rigorously analyzed. To understand how contact is used to explain cross-species spillovers, we conducted a multi-disciplinary review of studies addressing human-nonhuman primate (NHP) engagements and pathogenic transmissions and employing the term contact. We find that although contact is frequently invoked, it is employed inconsistently and imprecisely across these studies, overlooking the range of pathogens and their transmission routes and directions. We also examine a related but more expansive approach focusing on human and NHP habitats and their spatial overlap, which can potentially facilitate pathogenic transmission. Contact and spatial overlap investigations cannot, however, explain the processes that bring together people, animals and pathogens. We therefore examine another approach that enhances our understanding of zoonotic spillovers: anthropological studies identifying such historical, social, environmental processes. Comparable to a One Health approach, our ongoing research in Cameroon draws contact, spatial overlap and anthropologicalhistorical approaches into dialog to suggest where, when and how pathogenic transmissions between people and NHPs may occur. In conclusion, we call for zoonotic disease researchers to specify more precisely the human-animal contacts they investigate and to attend to how broader ecologies, societies and histories shape pathogen-human-animal interactions.
\end{abstract}

Keywords: Nonhuman primates, Disease emergence, Zoonosis, Human-animal contact, Spillover, One Health

\section{INTRODUCTION}

Electronic supplementary material: The online version of this article (https://doi. org/10.1007/s10393-017-1283-4) contains supplementary material, which is available to authorized users.

Correspondence to: Tamara Giles-Vernick, e-mail: tamara.giles-vernick@pasteur.fr 
importance. Analysts have identified multiple drivers of zoonotic transmission, including genetic proximity between hosts, a pathogen's adaptive ability and human-animal contact catalyzed by human demographic expansion, anthropogenically induced habitat fragmentation, hunting and butchering of animals (Davies and Pedersen 2008; see also Loy et al. 2017; van Vliet et al. 2017; Kurpiers et al. 2016; Mwangi et al. 2016).

Nearly two decades ago, Wolfe et al. (1998) observed that "(i)ncreasing human contact with forested systems almost certainly leads to a corresponding increase in the emergence of infections in the human population." This observation, which increased contact leads to greater risk of zoonotic disease transmission, has since been echoed in multiple studies (Mossoun et al. 2017; Kelly et al. 2017; Ahuka-Mundeke et al. 2017; Mossoun et al. 2015; Morse et al. 2012).

We concur that frequency of human-animal contact, among other factors, can increase zoonotic transmission risks. Yet the very basis of this proposition-the term contact-has not been rigorously analyzed, although some researchers investigating zoonotic transmission recognize that the term is often loosely defined. What contact is and how it drives the emergence of infectious diseases of zoonotic origin is an important question, with critical implications for the surveillance, identification and control of zoonotic disease, as well as the development and application of human health and wildlife conservation policies. For these reasons, we conducted a multi-disciplinary review of human-nonhuman primate (NHP) contact and pathogenic transmissions. We focused on human interactions with NHPs because of their genetic proximity, their many shared pathogens, and their prominence in this literature (Calvignac-Spencer et al. 2012; Davies and Pedersen 2008; Wolfe et al. 2007). Our aim was to evaluate the uses of contact to encourage further rigor and greater precision in evaluating how and why cross-species transmissions take place.

Developing a fuller understanding of zoonotic spillover necessitates using multiple investigative tools and concepts. To that end, we examine one approach focused on contact and a second, related but broader one, evaluating spatial overlap in human and NHP habitats which facilitates pathogenic transmission. In addition to these approaches, we discuss the use of anthropological-historical investigation to explore the long-term historical, social and environmental processes that bring together people, animals and pathogens. As a way of illustrating how contact, spatial and anthropological investigative approaches can illuminate how, when, where and why pathogenic exposures occur between people and NHPs, we describe our ongoing research in Cameroon.

\section{MetHODS}

In compiling this review, we initiated searches in the PubMed database with three different search strings: a general search concerning human-NHP contact and pathogenic transmission; a second that included specific, potentially zoonotic pathogens; and a third evoking human-NHP spatial overlaps and pathogenic transmission (Fig. 1). We conducted the latter two searches because the initial one did not consistently yield results for specific pathogens or spatial overlap, even though these search terms were pertinent to our research. We read all articles in English or French with online accessibility and included all those employing the term contact to assess human-NHP engagements and disease spillover; duplicates were deleted. To supplement this review, we conducted a manual search to identify relevant articles in the bibliographies of our PubMed search results. Supplementary file 1 lists all articles included in the systematic and manual searches.

Beyond this literature review, we included additional sources that did not address contact. Some illustrated alternative routes of pathogenic transmission beyond physical engagement with bodily fluids; other key works introduced theoretical anthropological reflections that could shed light on human-animal engagements and zoonotic emergence.

\section{Results}

Our search yielded 184 articles. Of these screened articles, $36.4 \%$ ( $n=67)$ used contact to refer primarily to physical contact with NHPs or their bodily fluids, even if they did not consistently define the term; $25.5 \%(n=47)$ addressed human-NHP spatial proximities/overlaps; $26.6 \% \quad(n=49)$ evoked both contact and spatial proximity; and $11.4 \%$ ( $n=21)$ used contact but left the term altogether undefined.

\section{Contact and Exposure}

Overall, we found that contact is deployed in multiple and inconsistent ways. Contact can be qualified as "direct," that is, a physical exposure to bodily fluids of an infected animal 


\section{Systematic search in PubMed}

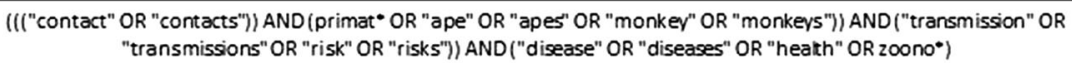

((("contact" OR "contacts")) AND (primat* OR "ape" OR "apes" OR "monkey" OR "monkeys")) AND ("transmission" OR "transmissions" OR "risk" OR "risks")) AND ("disease" OR "diseases" OR "heath" OR zoono"

( (C("retroviruses" OR "SIV" OR "HIV" OR "HTLV" OR "STLV" OR "PTLV" OR "strongylid" OR "strongylids" OR "strongyloides" OR "trichuris" $O R$ "whipworm" $O R$ "whipworms" $O R$ "ebola" $O R$ "marburg" OR "filovirus" $O R$ "filoviruses" $O R$ "simian foamy virus" $O R$ "hookworm" $O R$ "hookworms" $O R$ "nodular worm" $O R$ "nodular worms" $O R$ "ascaris" OR "oesophagostomum" OR "heiminth" OR "helminths" $O R$ "bacteria" OR "bacterias" $O R$ "monkeypox" OR

"herpes") AND ("contact" OR "contacts")) AND ("primate" OR "primates" OR "ape" OR "apes" OR "monkey" OR "monkeys")| AND ("human" OR "humans")) AND ("disease" OR "diseases" OR "heath" OR zoono*)

((( ("spatialoverlap" OR "habitat overlap" OR "spatial proximity")) AND ("primate" OR "primates" OR "ape" OR "apes" OR "monkey" OR "monkeys")| AND ("human" OR "humans")) AND("heath" OR "disease" OR "diseases" OR zono")

\section{Manual search}

From bibliographies of articles found in systematic search

\section{TOTAL}

\section{*Inclusion criteria:}

- Article in English or French with an accessible pdf

- "Contact » used to refer to human-NHP interactions for pathogenic spillover assessment

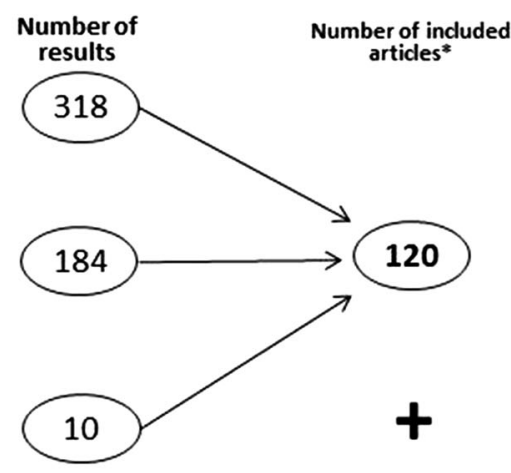

64

Fig. 1. Search methodology for literature review

through mucosal or wound exposure; however, this same "direct contact" can also refer to aerosolized contact with droplets of infected bodily fluids (Mossoun et al. 2017; Muehlenbein 2017; Kurpiers et al. 2016; Gilardi et al. 2015; Köndgen et al. 2008). It can be defined as "indirect" or "secondary," ranging from exposure to fomites, feces or vectors to inhabiting the same geographical zone (Kurpiers et al. 2016; Gilardi et al. 2015; Ravasi et al. 2012; Davies and Pedersen 2008; Wolfe et al. 2007). "Close contact," employed in multiple publications, can refer both to bodily proximity without physical engagement and to direct physical touching (Kurpiers et al. 2016; Gilardi et al. 2015; Rwego et al. 2008; Jones-Engel et al. 2006; Chapman et al. 2005; Muriuki et al. 1998). An exception is Tutin's (2000) overview of different types of contact between humans and NHP species in central Gabon to shed light on factors facilitating retroviral transmission.

At times, specific activities or social characteristics are said to facilitate contact and, in turn, serve as proxies for risk of exposure to a viral pathogen (Wolfe et al. 2005; Wolfe et al. 2007; Wolfe et al. 2004). For instance, Mossoun et al. (2015) argue that markers including gender, country of birth and ethnicity are positively associated with NHP contact, defined as hunting, dismembering, cooking or eating wild NHPs, as well as touching or being injured by NHP pets. These markers and the activities that they facilitate thus constitute a proxy for risk of zoonotic infection from NHPs. Although proxies are commonly used, in this case, broad markers such as country of birth or ethnic origin are inadequate indicators of the risk of exposure, even if statistically significant. For instance, decades of historical and anthropological research on ethnicity have demonstrated that ethnic origin is complex, dynamic and variable across populations, across national frontiers and over time (Harms 1981; Tonkin et al. 1998; Kuba et al. 2004). Using ethnic origin as a proxy for exposure risk assumes a highly reductive, misleading understanding of ethnic belonging. This broad, uninformative marker may mask other, more specific ones that could affect exposure risks. The group has since nuanced its argument, contending that other parameters must be accounted for in NHP-human spillovers, including pathogen prevalence in the NHP host species (Mossoun et al. 2017).

Activities facilitating direct, physical contact with NHP bodily fluids certainly do elevate the risk of certain pathogenic transmissions. But exclusive attention to direct contact with contaminated NHP bodily fluids through hunting and butchering is misleading: viral transmission routes can be diverse. We focus below on three examples of zoonotic emergence: HIV-1M, simian foamy virus and Ebola virus. Our choice of these three examples results from their prominence in the contact references amassed in our search (41\%). Closer analyses of these examples illustrate the shortcomings of a preoccupation with direct, physical contact through hunting and butchering, as well as the importance of evaluating other pathways of exposure. 
Phylogenetic analyses have identified SIVcpz (chimpanzee) as the simian ancestor of pandemic HIV-1M and argue for the emergence of into human beings between 1908 and 1933 (Faria et al. 2014; Peeters et al. 2014; Keele et al. 2006). To explain why this emergence occurred, some virologists and evolutionary biologists have signaled that this period coincides with European colonization of equatorial Africa, which they argue precipitated an influx of arms and concomitant increase in hunting and butchering of chimpanzees and other NHPs; increased hunting and butchering, it is reasoned, led to increased exposure to infected chimpanzees and resulted in the "cut hunter"- the purported index patient cut or injured by a chimpanzee infected with SIV (Pepin 2011; Peeters et al. 2014; Faria et al. 2014; De Sousa et al. 2010). But SIV transmission between NHP species seems to have multiple pathways, some of which do not result from hunting. For instance, SIV transmissions from green monkeys (Chlorocebus sabaeus) to Patas monkeys (Erythrocebus patas) occurred because of mutual grooming, delousing and biting; gorillas, infected by SIVcpz, are not known to hunt or eat meat (Bibollet-Ruche et al. 1996; Van Heuverswyn et al. 2006). The exclusive focus on hunting and butchering to explain SIVcpz emergence into human beings is unduly limited, relying on an inaccurate assumption of increased NHP hunting as a result of augmented firearm circulation among Africans (Rupp et al. 2016).

The primary transmission risk of simian foamy virus (SFV) from NHPs to humans comes from an animal bite because the virus is more replicative in saliva than in other bodily fluids (Falcone et al. 1999, Murray et al. 2006, 2008). Betsem et al. (2011) show that people bitten by great apes, primarily during hunting encounters, run an elevated risk of SFV infection (see also Gessain et al. 2013; MouingaOndémé et al. 2012). But again, there may be exceptions to this transmission pattern. Switzer et al. (2004) demonstrated that some laboratory workers who reported no bites from captive NHP were nonetheless infected with SFV. Switzer et al. (2012) subsequently showed in a non-captive setting in the Democratic Republic of Congo (DRC), two people having no contact at all with NHPs were nevertheless infected with SFV; their only identified risk factor was having "enter[ed] the forest." Switzer and colleagues thus suggest that environmental exposure to contaminated feces or urine may result in SFV transmission.

Finally, human-NHP engagements also appear to have catalyzed human outbreaks of Ebola virus. Although great apes are not considered Ebola virus reservoirs, direct contact with a chimpanzee during the butchering process has been linked to the 1999 and 2001-2003 human Ebola outbreaks in Gabon (Gonzales et al. 2012; Feldmann and Geisbert 2011; Georges-Courbot et al. 1997). And although direct, physical contact through butchering is most risky, laboratory experiments and field observations have identified other routes of transmission, including aerosolized transmission (Weingartl et al. 2012; Formenty et al. 1999; Johnson et al. 1995).

This overview and these examples show that contact with bodily fluids through hunting and butchering offers only partial explanations of NHP-human pathogenic transmissions. Leaving contact altogether undefined, or assuming that it occurs only through certain practices, neglects other routes of transmission, including touching contaminated feces or urine left on forest vegetation, or eating partially consumed fruits-both of which may be less risky but more frequent (Smiley Evans et al. 2016). Great ape attacks on people uninvolved in hunting, at agricultural or food gathering sites, can also occur and facilitate pathogenic transmission (Oishi 2013; Hockings et al. 2010; Wrangham et al. 2000).

\section{Another Approach to Contact: Spatial Overlaps and Proximities}

Other preoccupations, including the limitations of an unduly restricted notion of contact, have given rise to more spatial, ecological approaches to contact. The first, emerging primarily from primatology and conservation biology, examines drivers that facilitate a bidirectional transmission of diverse pathogens beyond viruses between NHPs and human beings, demonstrating that pathogen sharing or adaptation between NHPs and humans occurs when these species co-inhabit specific ecological spaces (Kouassi et al. 2015; Drakulovski et al. 2014; Liu et al. 2014; Lane-deGraaf et al. 2014; Salyer et al. 2012; Leendertz et al. 2008). Goldberg et al. (2008), for instance, argue that spatial proximities of NHPs, livestock and humans in Uganda influenced genetic similarities of E. coli found in each species, so that "[human] contact with primates occurs during excursions into fragments to extract forest resources (e.g., firewood, timber) or when primates leave fragments to raid crops." As evaluated here, contact does not result from touching of bodily fluids and does not conclude in viral transmission. Rather, it emerges from movement within a shared habitat, and as Goldberg and colleagues show, requires genetic verification of transmission, even when people and NHPs share the same potential pathogen. 
In contrast to literature addressing contact, research employing this spatial approach highlights another direction of pathogenic transmission, from human beings to NHPs. This is another consequence of human-NHP engagements. NHPs, especially great apes, are increasingly studied by ecologists, conservation biologists and others, generating new kinds of spatial engagements through observational research practices and at times ecotourism activities (Engel and Jones-Engel 2012). Habituated NHP groups, followed daily by local trackers, guards, researchers or tourists, are at increased risk of infection from people through aerosol, fecal-oral or vector transmissions and thus require protection from human exposure (Woodford et al. 2002).

Although several studies deploy the term contact in association with spatial overlap, they sometimes neglect to define the content of this term (Grützmacher et al. 2017; Muehlenbein 2016; Muhlenbein and Ancrenaz 2009; Köndgen et al. 2008). Nevertheless, several examples of pathogenic transmissions from humans to habituated great apes have been documented, including intestinal parasites (Sleeman et al. 2000; Cibot et al. 2015), protozoans (Sleeman et al. 2000), bacteria, including antibiotic-resistant strains (Rwego et al. 2008; Nizeyi et al. 2001), and respiratory viruses (Köndgen et al. 2008; Grützmacher et al. 2017). The potential for human spillovers into NHP populations and spillback could lead to new emergences in both populations (Morse et al. 2012).

Investigations of spatial proximities of humans and NHPs also appear to be a reaction to shortcomings of contact, defined as physical engagement with biological fluids, catalyzed by risky hunting and butchering practices. In an especially illuminating contribution, Paige et al. (2017) draw from social-ecological systems research to compare the overlap of human and NHP activities in five forest fragments of Uganda (on socio-ecological systems approach, see Ostrom 2009; Poteete et al. 2010, cited in Paige et al. 2017). In this fine-scale analysis, they show high variability across these five sites in human and NHP activities. "Hotspots" of human and NHP activities tended to be distant from one another, and substantial overlap occurred in one location, driven by human collection of firewood and herbal medicines. Overlap across forest fragments is far from uniform, and "decisions about outbreak mitigation must be place-specific and informed by local data" (Paige et al. 2017).

Spatial proximities of human and NHP activities do not always lead to increased contact and pathogenic spil- lover. One study in the Sebitoli area of Kibale National Park, Uganda, found that people and NHPs shared certain intestinal parasites (Oesophagostomum bifurcum and $O$. stephanostomum), likely facilitated by chimpanzee crop raiding of maize and their lack of avoidance of human beings (Cibot et al. 2015; Krief et al. 2014; Bortolamiol et al. 2014). But Narat et al. (2015), investigating a forest-savanna mosaic in a DRC community-based conservation area with high spatial overlap of human and bonobo (Pan paniscus) activity, found no shared intestinal helminths between these two populations. Without careful attention to the type and timing of human-NHP interaction or the types of pathogens shared, spatial overlap may not always effectively predict pathogenic transmission risk. Nevertheless, this approach does expand our attention beyond viruses to parasites and bacteria, their diverse directions and modes of transmission, and to fine-grained differences in ecological zones and activities.

Expanding Contact and Spatial Overlap Through Anthropological-Historical Investigation

Although works employing contact and spatial overlap elucidate the immediate circumstances and practices through which human beings and NHPs engage and potentially transmit pathogens, an anthropological-historical approach is useful because it draws attention to the changing ecological, political economic and social relations that bring about these engagements and pathogenic transmissions. Some anthropologists have argued that human bodies are not only in contact or spatial proximity with non-humans and pathogens, but "entangled" or "enmeshed" in "time and space, allowing the recognition of environmental, historical, political and sociocultural variables... [which] meld with the material body directly and indirectly" (Lock 2015; see also Lock and Nguyen 2010; Ingold 2011). These variables are not simply "contextual" or "background" evidence, but play a fundamental role in shaping patterns of health and disease transmission in specific locations. Brown and Kelly (2014), outlining an anthropology of hemorrhagic viral emergence, evoke a similar notion in their focus on the "material proximities" that create "hotspots"-the temporary convergences of people, animals and non-humans that reconfigure social, political economic and ecological relations and together facilitate viral emergence. Hunting, they remind us, is not simply a practice to acquire food or a public health risk facilitating zoonotic transmission; it configures and is 
configured by gender and generational relations, by available and changing technologies, by symbolic meanings of killing, sharing and consuming meat, by affective relations between hunters and animals themselves (Brown and Kelly 2014; Giles-Vernick and Rupp 2006). These broader relations and symbolic meanings affect how, when and why a hunter decides to kill an animal, shaping his or her exposure to zoonotic disease.

Anthropological-historical investigation of the affective, symbolic and relational dimensions of human-NHP engagements thus expands our attention from a single, finite interaction that may lead to exposure and infection to revealing how that interaction is configured by broader relations and processes. It is not enough to assert that risks of pathogenic exposure are heightened with human-NHP contact from specific practices, or with human-NHP spatial overlaps. Beyond analyses identifying practices or spatial proximities to increase transmission, anthropological and historical research would carefully document who engages in practices that increase risk of zoonotic transmission, the material and affective content of such practices, and the historical, political, economic and sociocultural processes and logics that shape when, where, how and why people pursue these practices.

Bringing Together Contact, Spatial Overlap and Anthropological-Historical Investigation in Cameroon

Our ongoing multi-disciplinary research in southeastern Cameroon illustrates how a more precise definition of contact, spatial overlap analyses and anthropological-historical approach can be enmeshed, to develop a rigorous approach to the multiple engagements between human beings, NHPs and pathogens (Fig. 2, showing our three approaches and methods). For over one year, we have collected the daily activities and movements of 18 volunteers inhabiting this dense equatorial rainforest and making their living through farming, hunting and gathering. Our

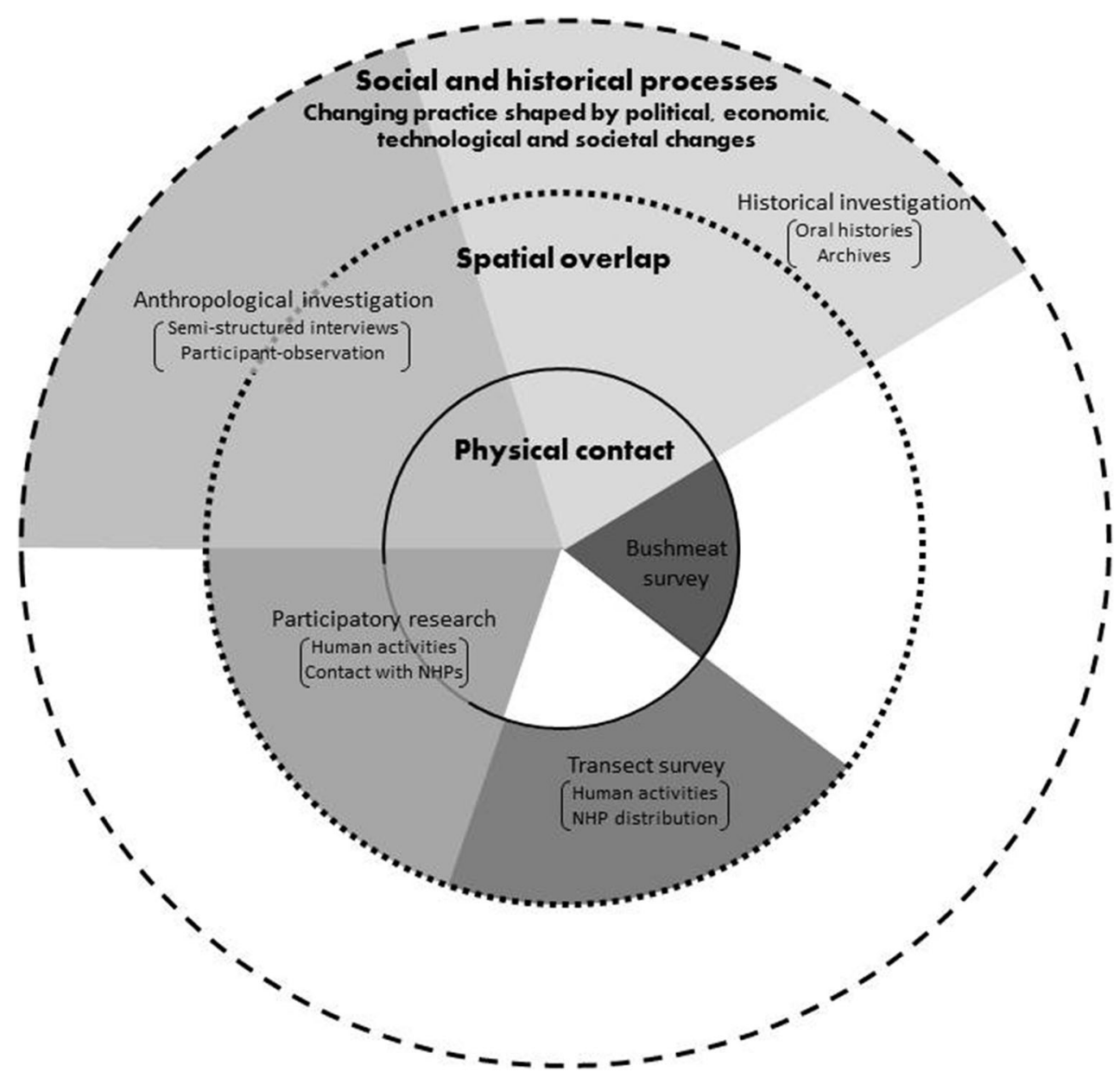

Fig. 2. Integrating contact, spatial and anthropological-historical investigation in Cameroon 
volunteers document their precise contacts with NHPs, noting the range of engagements-from seeing the stools of one of nine NHPs inhabiting this region, to encounters with primates pillaging fields, to the precise techniques of hunting or butchering NHP meat-and mapping locations these contacts within a $1-\mathrm{km}^{2}$ zone in the forest. This evidence provides insight into physical contact and spatial overlaps with NHPs. Monthly transects are also conducted to document temporal changes in NHP presence and estimated density and in their spatial overlap with human activities. We also engaged in fine-grained participantobservation and open-ended historical interviews that provide insight into political, ecological, economic, social and technological changes shaping human-NHP engagements. Together, these precise definitions of contact, documentation of spatial overlaps between NHPs and humans and in-depth investigation of changing practices and the broad forces framing them yield insight into varied exposures and risks across social groups and over time.

Our initial results from these diverse methods indicate, for instance, that the particularities of butchering practices matter considerably for human exposure to NHP bodily fluids and that the last 20 years have seen important changes in these practices and have potentially altered exposure to NHP disease transmission risk across social groups (unpublished data). Hunters recount significant changes in the butchering of great apes. Most butchering used to occur within villages; exposure to potentially contaminated blood would have been equally likely across men and women, since male hunters would initially cut the biggest pieces of their kill in the forest, but then transport the fresh meat to villages, where women and men would follow up by making smaller cuts of fresh meat. But due to economic recession and an expansion in state and conservation organizations' protection of great apes in recent years, hunters butcher gorillas and chimpanzees immediately after killing them, cutting the meat into small pieces and drying it directly over the fire before returning to villages to sell in informal markets. Gorilla pelts and bones are now cut away from the carcasses to hide evidence of a kill, exposing those butchering in the forest to further risk from inadvertent cuts. Previously, when a gorilla pillaging gardens near the village was killed, the hunters would call village children to dance around the carcass in celebration. This celebration of the death of a marauding gorilla no longer occurs, since it would attract unwanted attentions of conservation authorities. As one aging but still-active hunter explained, "now.. [great ape hunting is] forbidden, so we do everything [butchering] in the forest." Exposure to fresh blood is thus largely limited to hunters themselves, although it remains unknown whether certain viruses can be transmitted via smoked meat. Butchering of hunted monkeys seems not to have changed over time: the carcasses are immediately put over the fire to singe off the fur and to "harden" (coagulate) the blood, entailing less potentially pathogenic blood exposure for hunters. Our preliminary findings therefore indicate that these butchering techniques for different NHP species may entail different risks of biological fluid exposure.

For a researcher investigating risk of pathogenic exposures, this brief example illustrates that "butchering" is not a single, fixed practice heightening the risk of pathogenic transmission within a single, undifferentiated population. It needs considerable refinement to show how human physical engagement with NHP carcasses leads to heightened exposure among particular social groups. Butchering techniques can differ for different species and can change over time because of changing economic and political conditions, implicating different gender and generational groups, altered affective relations with great apes (and their carcasses) and varied potential exposures to infection. It also demonstrates that rigorous analysis of defined human-NHP contacts, combined with an examination of spatial overlap and the enmeshment of pathogenic exposure with human practice and social, historical, political economic change, can provide genuine insight into human-NHP spillover risks.

\section{CONCLUSION}

Contact is a widely employed term in studies seeking to explain pathogenic transmissions between humans and NHPs. At times, the term is used without definition, whereas elsewhere, its forms have proliferated, but without consistency. We sought to alert researchers to the inconsistent usage of contact and to encourage them to specify what they mean when using the term, thereby offering greater precision in evaluating how and why cross-species transmissions take place.

Greater precision means not only defining specific types of contact between humans and NHPs, but also expanding our sights beyond a narrow range of transmission routes and viruses. It means recognizing that the pathogens, their directions and modes of transmission, and ecological zones are variable, as the spatial overlap ap- 
proach has recently emphasized. It also entails acknowledging, as anthropological approaches do, that people and their activities are not uniform; they vary across social groups, time and locations because of ecological, social and political economic changes. A more precise grappling with contact demands, then, the kind of multi-disciplinary investigation that One Health seeks to foster. Our recommendations to bring into dialog more specific definitions of contact, spatial overlap and anthropological-historical analyses would bring greater rigor to analyses of where, when and how pathogenic transmissions between people and NHPs occur. This approach would yield more careful, nuanced attention to experiences of people living on the frontlines of zoonotic transmissions and more insightful research into the changing dynamics of exposure and spillover risks.

\section{ACKNOWLEDGEMENTS}

This study was funded by the Agence Nationale de la Recherche (France) (Grant no. ANR-14-CE31-0004-01), with additional contributions from the "Humans and the Microbiome" project of the Canadian Institute for Advanced Research and the Fyssen Foundation. We thank Antoine Gessain and Yusuke Shimakawa for stimulating exchanges about contact, as well as people in southeastern Cameroon for their generous contributions to the study described here. We are also grateful to EcoHealth's anonymous reviewers for their helpful evaluations.

\section{REFERENCES}

Ahuka-Mundeke S, Ayouba A, Mbala-Kingebeni Foncelle C, Mubonga Ndimbo-Kumugo SP, Lunguya-Metila O, MbenzoAbokome V, Muyembe-Tamfum JJ, Delaporte E, Peeters M (2017) High Prevalences and a Wide Genetic Diversity of Simian Retroviruses in Non-human Primate Bushmeat in Rural Areas of the Democratic Republic of Congo. EcoHealth 14:100114. https://doi.org/10.1007/s10393-017-1223-3

Betsem E, Rua R, Tortevoye P, Froment A, Gessain A (2011) Frequent and Recent Human Acquisition of Simian Foamy Viruses Through Apes' Bites in Central Africa. PLoS Pathogens 7:e1002306 . https://doi.org/10.1371/journal.ppat.1002306

Bibollet-Ruche F, Galat-Luong A, Cuny G, Sarni-Manchado P, Galat G, Durand JP, Pourrut X, Veas F (1996) Simian immunodeficiency virus infection in a patas monkey (Erythrocebus patas): evidence for cross-species transmission from African green monkeys (Cercopithecus aethiops sabaeus) in the wild. The Journal of General Virology 77:773-781
Bortolamiol S, Cohen M, Potts K, Pennec F, Rwaburindore P, Kasenene J, Seguya A, Vignaud Q, Krief S (2014) Suitable Habitats for Endangered Frugivorous Mammals: Small-Scale Comparison, Regeneration Forest and Chimpanzee Density in Kibale National Park, Uganda. PLoS One 9:e102177 . https:// doi.org/10.1371/journal.pone.0102177

Brown H, Kelly A (2014) Material Proximities and Hotspots: Toward an Anthropology of Viral Hemorrhagic Fevers. Medical Anthropology Quarterly 28:280-303. https://doi.org/10.1111/ maq.12092

Calvignac-Spencer S, Leendertz SAJ, Gillespie TR, Leendertz FH (2012) Wild great apes as sentinels and sources of infectious disease. Clinical Microbiology and Infection 18:521-527. https:// doi.org/10.1111/j.1469-0691.2012.03816.x

Chapman CA, Gillespie TR, Goldberg TL (2005) Primates and the Ecology of their Infectious Diseases: How will Anthropogenic Change Affect Host-Parasite Interactions? Evolutionary Anthropology: Issues, News, and Reviews 14:134-144

Cibot M, Guillot J, Lafosse S, Bon C, Seguya A, Krief S (2015) Nodular Worm Infections in Wild Non-Human Primates and Humans Living in the Sebitoli Area (Kibale National Park, Uganda): Do High Spatial Proximity Favor Zoonotic Transmission? PLoS Neglected Tropical Diseases 9:e0004133. https:// doi.org/10.1371/journal.pntd.0004133

Davies TJ, Pedersen AB (2008) Phylogeny and geography predict pathogen community similarity in wild primates and humans. Proceedings of the Royal Society B: Biological Sciences 275:16951701. https://doi.org/10.1098/rspb.2008.0284

de Sousa JD, Müller V, Lemey P, Vandamme A-M (2010) High GUD Incidence in the Early 20th Century Created a Particularly Permissive Time Window for the Origin and Initial Spread of Epidemic HIV Strains. PLoS One 5:e9936. https://doi.org/ 10.1371/journal.pone.0009936

Drakulovski P, Bertout S, Locatelli S, Butel C, Pion S, MpoudiNgole E, Delaporte E, Peeters M, Mallié M (2014) Assessment of gastrointestinal parasites in wild chimpanzees (Pan troglodytes troglodytes) in southeast Cameroon. Parasitology Research 113:2541-2550. https://doi.org/10.1007/s00436-014-3904-y

Engel GA, Jones-Engel L (2012) Primates and primatologists: social contexts for interspecies pathogen transmission. American journal of primatology 74(6):543-550. https://doi.org/10.1002/ ajp.20988

Falcone V, Leupold J, Clotten J, Urbanyi E, Herchenröder O, Spatz W, Volk B, Böhm N, Toniolo A, Neumann-Haefelin D, Schweizer M (1999) Sites of Simian Foamy Virus Persistence in Naturally Infected African Green Monkeys: Latent Provirus Is Ubiquitous, Whereas Viral Replication Is Restricted to the Oral Mucosa. Virology 257:7-14

Faria NR, Rambaut A, Suchard MA, Baele G, Bedford T, Ward MJ, Tatem AJ, Sousa JD, Arinaminpathy N, Pépin J, Posada D, Peeters M, Pybus OG, Lemey P (2014) The early spread and epidemic ignition of HIV-1 in human populations. Science 346:56-61. https://doi.org/10.1126/science.1256739

Feldmann H, Geisbert TW (2011) Ebola haemorrhagic fever. The Lancet 377:849-862. https://doi.org/10.1016/S0140-6736(10) 60667-8

Formenty P, Boesch C, Wyers M, Steiner C, Donati F, Dind F, Walker F, Le Guenno B (1999) Ebola virus outbreak among wild chimpanzees living in a rain forest of Cote d'Ivoire. Journal of Infectious Diseases 179:S120-S126

Georges-Courbot MC, Sanchez A, Lu CY, Baize S, Leroy E, Lansout-Soukate J, Tévi-Bénissan C, Georges AJ, Trappier SG, Zaki 
SR, Swanepoel R, Leman PA, Rollin PE, Peters CJ, Nichol ST, Ksiazek TG (1997) Isolation and phylogenetic characterization of Ebola viruses causing different outbreaks in Gabon. Emerging Infectious Diseases 3:59-62

Gessain A, Rua R, Betsem E, Turpin J, Mahieux R (2013) HTLV$3 / 4$ and simian foamy retroviruses in humans: Discovery, epidemiology, cross-species transmission and molecular virology. Virology 435:187-199. https://doi.org/10.1016/j.virol.2012.09. 035

Gilardi KV, Gillespie TR, Leendertz FH, Macfie EJ, Travis DA, Whittier CA, Williamson EA (2015) Best Practice Guidelines for Health Monitoring and Disease Control in Great Ape Populations, Gland, Switzerland: IUCN SSC Primate Specialist Group

Giles-Vernick T, Rupp S (2006) Visions of Apes, Reflections on Change: Telling Tales of Great Apes in Equatorial Africa. African Studies Review 49:51-73

Goldberg TL, Gillespie TR, Rwego IB, Estoff EL, Chapman CA (2008) Forest Fragmentation as Cause of Bacterial Transmission among Nonhuman Primates, Humans, and Livestock, Uganda. Emerging Infectious Diseases 14:1375-1382. https://doi.org/10. 3201/eid1409.071196

Gonzales JP, Prugnolle F, Leroy E (2012) Men, Primates and Germs: An Ongoing Affair. In: "One Health: The Human-Animal-Environment Interfaces in Emerging Diseases", Current Topics in Microbiology and Immunology, 365, Mackenzie JS, Jeggo M, Daszak P, Richt JA (editors), Cham, Switzerland: Springer, pp 337-353

Grützmacher K, Keil V, Leinert V, Leguillon F, Henlin A, CouacyHymann E, Köndgen S, Lang A, Deschner T, Wittig RM, Leendertz FH (2017) Human quarantine: Toward reducing infectious pressure on chimpanzees at the Taï Chimpanzee Project. Côte d'Ivoire. American Journal of Primatology. https:// doi.org/10.1002/ajp.22619

Harms R (1981) River of Wealth, River of Sorrow: The Central Zaire Basin in the Era of the Slave and Ivory Trade, 1500-1891, New Haven: Yale University Press

Hockings KJ, Yamakoshi G, Kabasawa A, Matsuzawa T (2010) Attacks on local persons by chimpanzees in Bossou, Republic of Guinea: long-term perspectives. American Journal of Primatology 72:887-896. https://doi.org/10.1002/ajp.20784

Ingold T (2011) Being Alive, London: Routledge

Johnson E, Jaax N, White J, Jahrling P (1995) Lethal experimental infections of rhesus monkeys by aerosolized Ebola virus. International journal of experimental pathology 76:227

Jones KE, Patel NG, Levy MA, Storeygard A, Balk D, Gittleman JL, Daszak P (2008) Global trends in emerging infectious diseases. Nature 451:990-993. https://doi.org/10.1038/nature06536

Jones-Engel L, Engel GA, Heidrich J, Chalise M, Poudel N, Viscidi R, Barry PA, Allan JS, Grant R, Kyes R (2006) Temple monkeys and health implications of commensalism, Kathmandu. Nepal. Emerging infectious diseases 12(6):900. https://doi.org/10.3201/ eid1206.060030

Keele BF, Heuverswyn FV, Li Y, Bailes E, Takehisa J, Santiago ML, Bibollet-Ruche F, Chen Y, Wain LV, Liegeois F, Loul S, Ngole EM, Bienvenue Y, Delaporte E, Brookfield JFY, Sharp PM, Shaw GM, Peeters M, Hahn BH (2006) Chimpanzee Reservoirs of Pandemic and Nonpandemic HIV-1. Science 313:523-526. https://doi.org/10.1126/science.1126531

Kelly TR, Karesh WB, Johnson CK, Gilardi KVK, Anthony SJ, Goldstein T, Olson SH, Machalaba C, Mazet JAK (2017) One Health proof of concept: Bringing a transdisciplinary approach to surveillance for zoonotic viruses at the human-wild animal interface. Preventive Veterinary Medicine 137:112-118. https:// doi.org/10.1016/j.prevetmed.2016.11.023

Köndgen S, Kühl H, N'Goran PK, Walsh PD, Schenk S, Ernst N, Biek R, Formenty P, Mätz-Rensing K, Schweiger B, Junglen S, Ellerbrok H, Nitsche A, Briese T, Lipkin WI, Pauli G, Boesch C, Leendertz FH (2008) Pandemic Human Viruses Cause Decline of Endangered Great Apes. Current Biology 18:260-264. https:// doi.org/10.1016/j.cub.2008.01.012

Kouassi RY, McGraw SW, Yao PK, Abou-Bacar A, Brunet J, Pesson B, Bonfoh B, N'goran EK, Candolfi E (2015) Diversity and prevalence of gastrointestinal parasites in seven non-human primates of the Taï National Park, Côte d'Ivoire. Parasite 22:1. https://doi.org/10.1051/parasite/2015001

Krief S, Cibot M, Bortolamiol S, Seguya A, Krief J-M, Masi S (2014) Wild chimpanzees on the edge: Nocturnal activities in croplands. PLoS One 9:e10992. https://doi.org/10.1371/journal. pone. 0109925

Kuba RIn: Lentz CSomda C (editors) (2004) Histoire du peuplement et relations interethniques au Burkina Faso, Paris: Harmattan

Kurpiers LA, Schulte-Herbrüggen B, Ejotre I, Reeder DM (2016) Bushmeat and Emerging Infectious Diseases: Lessons from Africa. In: Problematic Wildlife, Angelici FM (editor), Cham, Switzerland: Springer International Publishing, pp 507-551

Lane-deGraaf KE, Putra IGA, Wandia IN, Rompis A, Hollocher H, Fuentes A (2014) Human behavior and opportunities for parasite transmission in communities surrounding long-tailed macaque populations in Bali. Indonesia. American journal of primatology 76(2):159-167. https://doi.org/10.1002/ajp.22218

Leendertz FH, Zirkel F, Couacy-Hymann E, Ellerbrok H, Morozov VA, Pauli G, Hedemann C, Formenty P, Jensen SA, Boesch C, Junglen S (2008) Interspecies Transmission of Simian Foamy Virus in a Natural Predator-Prey System. Journal of Virology 82:7741-7744. https://doi.org/10.1128/JVI.00549-08

Liu W, Li Y, Shaw KS, Learn GH, Plenderleith LJ, Malenke JA, Sundararaman SA, Ramirez MA, Crystal PA, Smith AG, Bibollet-Ruche F, Ayouba A, Locatelli S, Esteban A, Mouacha F, Guichet E, Butel C, Ahuka-Mundeke S, Inogwabini B-I, Ndjango J-BN, Speede S, Sanz CM, Morgan DB, Gonder MK, Kranzusch PJ, Walsh PD, Georgiev AV, Muller MN, Piel AK, Stewart FA, Wilson ML, Pusey AE, Cui L, Wang Z, Färnert A, Sutherland CJ, Nolder D, Hart JA, Hart TB, Bertolani P, Gillis A, LeBreton M, Tafon B, Kiyang J, Djoko CF, Schneider BS, Wolfe ND, Mpoudi-Ngole E, Delaporte E, Carter R, Culleton RL, Shaw GM, Rayner JC, Peeters M, Hahn BH, Sharp PM (2014) African origin of the malaria parasite Plasmodium vivax. Nature Communications 5:3346 . https://doi.org/10.1038/ ncomms 4346

Lloyd-Smith JO, George D, Pepin KM, Pitzer VE, Pulliam JRC, Dobson AP, Hudson PJ, Grenfell BT (2009) Epidemic Dynamics at the Human-Animal Interface. Science 326:1362-1367. https:// doi.org/10.1126/science. 1177345

Lock M (2015) Comprehending the Body in the Era of the Epigenome. Current Anthropology 56:151-177. https://doi.org/ $10.1086 / 680350$

Lock M, Nguyen V-K (2010) An Anthropology of Biomedicine, Oxford: Wiley

Loy DE, Liu W, Li Y, Learn GH, Plenderleith LJ, Sundararaman SA, Sharp PM, Hahn BH (2017) Out of Africa: origins and evolution of the human malaria parasites Plasmodium falciparum and Plasmodium vivax. International journal for parasitology 47(2):87-97. https://doi.org/10.1016/j.ijpara.2016.05. 008 
Morse SS, Mazet JA, Woolhouse M, Parrish CR, Carroll D, Karesh WB, Zambrana-Torrelio C, Lipkin WI, Daszak P (2012) Prediction and prevention of the next pandemic zoonosis. The Lancet 380:1956-1965. https://doi.org/10.1016/S0140-6736(12) 61684-5

Mossoun A, Pauly M, Akoua-Koffi C, Couacy-Hymann E, Leendertz SAJ, Anoh AE, Gnoukpoho AH, Leendertz FH, Schubert G (2015) Contact to Non-Human Primates and Risk Factors for Zoonotic Disease Emergence in the Taï Region, Côte d'Ivoire. EcoHealth 12:580-591. https://doi.org/10.1007/s10393-0151056-X

Mossoun A, Calvignac-Spencer S, Anoh AE, Pauly MS, Driscoll DA, Michel AO, Nazaire LG, Pfister S, Sabwe P, Thiesen U, Vogler BR, Wiersma L, Muyembe-Tamfum J-J, Karhemere S, Akoua-Koffi C, Couacy-Hymann E, Fruth B, Wittig RM, Leendertz FH, Schubert G (2017) Bushmeat Hunting and Zoonotic Transmission of Simian T-Lymphotropic Virus 1 in Tropical West and Central Africa. Journal of Virology 91:e0247916. https://doi.org/10.1128/JVI.02479-16

Mouinga-Ondémé A, Caron M, Nkoghé D, Telfer P, Marx P, Saïb A, Leroy E, Gonzalez J-P, Gessain A, Kazanji M (2012) CrossSpecies Transmission of Simian Foamy Virus to Humans in Rural Gabon, Central Africa. Journal of Virology 86:1255-1260. https://doi.org/10.1128/JVI.06016-11

Muehlenbein MP (2016) Disease and Human/Animal Interactions. Annual Review of Anthropology 45:395-416. https:// doi.org/10.1146/annurev-anthro-102215-10003

Muehlenbein MP (2017) Primates on display: Potential disease consequences beyond bushmeat. American Journal of Physical Anthropology 162:32-43. https://doi.org/10.1002/ajpa.23145

Muhlenbein MP, Ancrenaz M (2009) Minimizing pathogen transmission at primate ecotourism destinations: the need for input from travel medicine. Journal of Travel Medicine 16:229232. https://doi.org/10.1111/j.1708-8305.2009.00346.x

Muriuki SMK, Murugu RK, Munene E, Karere GM, Chai DC (1998) Some gastro-intestinal parasites of zoonotic (public health) importance commonly observed in old world non-human primates in Kenya. Acta Tropica 71:73-82

Murray SM, Picker LJ, Axthelm MK, Linial ML (2006) Expanded Tissue Targets for Foamy Virus Replication with Simian Immunodeficiency Virus-Induced Immunosuppression. Journal of Virology 80:663-670

Murray SM, Picker LJ, Axthelm MK, Hudkins K, Alpers CE, Linial ML (2008) Replication in a superficial epithelial cell niche explains the lack of pathogenicity of primate foamy virus infections. Journal of Virology 82:5981-5985. https://doi.org/10.1128/ JVI.00367-08

Mwangi W, de Figueiredo P, Criscitiello MF (2016) One health: Addressing global challenges at the nexus of human, animal, and environmental health. PLoS Pathogens 12:e1005731. https:// doi.org/10.1371/journal.ppat.1005731

Narat V, Guillot J, Pennec F, Lafosse S, Grüner AC, Simmen B, Bokika Ngawolo JC, Krief S (2015) Intestinal Helminths of Wild Bonobos in Forest-Savanna Mosaic: Risk Assessment of CrossSpecies Transmission with Local People in the Democratic Republic of the Congo. EcoHealth 12:621-633. https://doi.org/ 10.1007/s10393-015-1058-8

Nizeyi JB, Innocent RB, Erume J, Kalema GRNN, Cranfield MR, Graczyk TK (2001) Campylobacteriosis, Salmonellosis, and Shigellosis in Free-Ranging Human-Habituated Mountain Gorillas of Uganda. Journal of Wildlife Diseases 37:239-244
Oishi T (2013) Human-Gorilla and Gorilla-Human: Dynamics of Human-animal boundaries and interethnic relationships in the central African rainforest. Revue de primatologie (Online) 5:63

Ostrom E (2009) A General Framework for Analyzing Sustainability of Social-Ecological Systems. Science 325:419-422. https://doi.org/10.1126/science.1172133

Paige SB, Bleecker J, Mayer J, Goldberg T (2017) Spatial Overlap Between People and Non-human Primates in a Fragmented Landscape. EcoHealth 14(1):88-99. https://doi.org/10.1007/ s10393-016-1194-9

Peeters M, D'Arc M, Delaporte E (2014) The origin and diversity of human retroviruses. AIDS reviews 16:23-34

Pepin J (2011) The Origins of AIDS, Cambridge: Cambridge University Press

Poteete AR, Janssen MA, Ostrom E (2010) Working together: collective action, the commons, and multiple methods in practice, Princeton, NJ: Princeton University Press

Ravasi DF, O’Riain MJ, Davids F, Illing N (2012) Phylogenetic evidence that two distinct trichuris genotypes infect both humans and non-human primates. PLoS One 7:e44187. https://doi. org/10.1371/journal.pone.0044187

Rupp S, Ambata P, Narat V, Giles-Vernick T (2016) Beyond the Cut Hunter: A Historical Epidemiology of HIV Beginnings in Central Africa. EcoHealth 13:661-671. https://doi.org/10.1007/ s10393-016-1189-6

Rwego IB, Isabirye-Basuta G, Gillespie TR, Goldberg TL (2008) Gastrointestinal Bacterial Transmission among Humans, Mountain Gorillas, and Livestock in Bwindi Impenetrable National Park, Uganda. Conservation Biology 22:1600-1607. https://doi.org/10.1111/j.1523-1739.2008.01018.x

Salyer SJ, Gillespie TR, Rwego IB, Chapman CA, Goldberg TL (2012) Epidemiology and molecular relationships of cryptosporidium spp. in people, primates, and livestock from Western Uganda. PLoS Neglected Tropical Diseases 6:e1597. https://doi.org/10.1371/journal.pntd.0001597

Sleeman JM, Meader L, Mudakikwa A, Foster J, Patton S (2000) Gastrointestinal Parasites of Mountain Gorillas (Gorilla gorilla beringei) in the Parc National des Volcans, Rwanda. Journal of Zoo and Wildlife Medicine 31:322-328

Smiley Evans T, Gilardi KV, Barry PA, Ssebide BJ, Kinani JF, Nizeyimana F, Noheri JB, Byaruqaba DK, Mudakilwa A, Cranfield MR, Mazet JA, Johnson CK (2016) Detection of viruses using discarded plants from wild mountain gorillas and golden monkeys. American journal of primatology 78(11):12221234. https://doi.org/10.1002/ajp.22576

Switzer WM, Bhullar V, Shanmugam V, Cong M-E, Parekh B, Lerche NW, Yee JL, Ely JJ, Boneva R, Chapman LE, Folks TM, Heneine W (2004) Frequent Simian Foamy Virus Infection in Persons Occupationally Exposed to Nonhuman Primates. Journal of Virology 78:2780-2789

Switzer WM, Tang S, Ahuka-Mundeke S, Shankar A, Hanson DL, Zheng $\mathrm{H}$, Ayouba A, Wolfe ND, LeBreton M, Djoko CF, Tamoufe U, Esteban A, Heneine W, Peeters M, Wright LL, Muyembe-Tamfum JJ, Wemakoy EO, Mulembakani P, Hoff NA, Rimoin AW (2012) Novel simian foamy virus infections from multiple monkey species in women from the Democratic Republic of Congo. Retrovirology 9:100. https://doi.org/10.1186/ 1742-4690-9-100

Tonkin E, McDonald M, Chapman MK (eds) (1998) History and ethnicity (Vol. 27). Routledge. 
Tutin CEG (2000) Ecologie et organisation sociale des primates de la forêt tropicale africaine: aide à la compréhension de la transmission des retrovirus. Bull Soc Pathol Exot 93:61-65

Van Heuverswyn F, Li Y, Neel C, Bailes E, Keele BF, Liu W, Loul S, Butel C, Liegeois F, Bienvenue Y, Ngolle EM, Sharp PM, Shaw GM, Delaporte E, Hahn BH, Peeters M (2006) Human immunodeficiency viruses: SIV infection in wild gorillas. Nature 444:164 . https://doi.org/10.1038/444164a

Van Vliet N, Moreno J, Gomez J, Zhou W, Fa JE, Golden C, Nobrega Alves RR, Nasi R (2017) Bushmeat and Human Health: Assessing the Evidence in Tropical and sub-Tropical Forests. Ethnobiology and Conservation 6:1-44. https://doi.org/ 10.15451/ed2017-04-6.3-1-45

Weingartl HM, Embury-Hyatt C, Nfon C, Leung A, Smith G, Kobinger G (2012) Transmission of Ebola virus from pigs to non-human primates. Scientific Reports 2:1-4. https://doi.org/ 10.1038/srep00811

Wolfe ND, Escalante AA, Karesh WB, Kilbourn A, Spielman A, Lal AA (1998) Wild primate populations in emerging infectious disease research: the missing link? Emerging infectious diseases 4:149-158. https://doi.org/10.3201/eid0402.980202
Wolfe ND, Prosser TA, Carr JK, Tamoufe U, Mpoudi-Ngole E, Torimiro JN, LeBreton M, McCutchan FE, Birx DL, Burke DS (2004) Exposure to nonhuman primates in rural Cameroon. Emerg Infect Dis 10:2094-2099. https://doi.org/10.3201/eid1012.040062

Wolfe ND, Heneine W, Carr JK, Garcia AD, Shanmugam V, Tamoufe U, Torimiro JN, Prosser AT, LeBreton M, MpoudiNgole E, McCutchan FE, Birx DL, Folks TM, Burke DS, Switzer WM (2005) Emergence of unique primate T-lymphotropic viruses among central African bushmeat hunters. Proceedings of the National Academy of Sciences 102:7994-7999. https:// doi.org/10.1073/pnas.0501734102

Wolfe ND, Dunavan CP, Diamond J (2007) Origins of major human infectious diseases. Nature 447:279-283. https://doi.org/ 10.1038 /nature 05775

Woodford MH, Butynski TM, Karesh WB (2002) Habituating the great apes: the disease risks. Oryx 36:153-160

Wrangham R, Wilson M, Hare B, Wolfe ND (2000) Chimpanzee Predation and the Ecology of Microbial Exchange. Microbial Ecology in Health and Disease 12:186-188 